\title{
ANALISIS SEKTOR EKONOMI UNGGULAN DALAM PENGEMBANGAN POTENSI PEREKONOMIAN DI PROVINSI KALIMANTAN UTARA
}

\author{
ANALYSIS OF THE LEADING ECONOMIC SEKTORS IN THE DEVELOPMENT \\ POTENTIAL OF THE ECONOMY IN THE PROVINCE OF NORTH BORNEO \\ Syaiful Anwar ${ }^{1)}$, Indriani ${ }^{2)}$ \\ (Universitas Borneo Tarakan) \\ Email: saiful.borneotarakan@gmail.com
}

\begin{abstract}
Abtrack: Penelitian ini bertujuan untuk mengetahui perubahan struktur ekonomi, dampak pertumbuhan ekonomi nasional dan sektoral nasional terhadap perekonomian dan sektor ekonomi unggulan di Provinsi Kalimantan Utara. Jenis Penelitian ini adalah penelitian kuantitatif. Data yang digunakan dalam penelitian ini adalah data sekunder berupa data time series yang diperoleh dari BPS.

Alat analisis yang digunakan dalam penelitian ini adalah analisis Shift Share terbagi atas tiga komponen yakni komponen pertumbuhan ekonomi nasional (Nij), pengaruh bauran industri (Mij) dan pengaruh keunggulan kompetitif. Dari hasil analisis penelitian di peroleh bahwa nilai Nij memberikan respon positif yakni sebesar Rp 15.769,41 miliar rupiah. Nilai Mij memberikan respon negatif yakni sebesar $R p$ 3.603,09 miliar rupiah. Nilai Cij memberikan respon positif yakni sebesar Rp 7.711,39 miliar rupiah..
\end{abstract}

Kata Kunci: Analisis Shift Share, Pertumbuhan Ekonomi, Perubahan Struktur Ekonomi, Sektor Ekonomi Unggulan

Abstract: This research aims to know the change of the economic structure, the impact of national and sectoral economic growth in the national economy and the leading economic sectors in the province of North Borneo. Type of this research is quantitative research. The data used in this research is a form of secondary data is data the time series obtained from BPS.

Analytical tools used in this study is the analysis of Shift Share is divided into three components namely national economic growth component (Nij), the industrial mix influence (Mij) and the influence of competitive advantage. Analysis of the results obtained in the research that the value of the Nij provide positive response i.e. $R p$ 15,769.41 billion rupiah. The value of negative response gives the Mij i.e. Rp 3,603.09 billion rupiah. The value Cij give positive response i.e. $R p$ 7,711.39 billion rupiah.

Keywords: Shift Share Analysis, Economic Growth, Economic Structure Changes, The Superior Sector Of The Economy

\section{LATAR BELAKANG}

Istilah ekonomidigunakan secara bergantian dengan istilah seperti pertumbuhan ekonomi, kesejahteraan ekonomi, kemajuan ekonomi dan perubahan jangka panjang. Perkembangan ekonomi dapat dipergunakan untuk menggambarkan faktor-faktor penentu yang mendasari pertumbuhan ekonomi, seperti perubahan dalam teknik produksi, sikap masyarakat dan lembaga-lembaga. Perubahan tersebut dapat menghasilkan pertumbuhan ekonomi (Jhingan, 2010).

Pertumbuhan ekonomi yaitu kenaikan kapasitas produksi jangka panjang yang diwujudkan dalam bentuk pendapatan. Pertumbuhan ekonomi daerah merupakan tolak ukur perekonomian suatu 
daerah tersebut. Pertumbuhan ekonomi yang tinggi dan berkelanjutan merupakan kondisi keharusan bagi kelangsungan pembangunan ekonomi dan peningkatan kesejahteraan masyarakat.

Pada pembangunan ekonomi di daerah, tujuan pembangunan itu sendiri tidak jauh berbeda dengan tujuan pembangunan nasional. Akan tetapi, proses pembangunan di daerah jauh lebih spesifik (Tambunan, 2001). Pembangunan ekonomi daerah dapat dikatakan berhasil yaitu dengan menggunakan ukuran dan beberapa indikator yang lazim digunakan sebagai alat ukur. Indikator yang lazim digunakan adalah produk domestik regional bruto (PDRB) yang biasa menjadi petunjuk kinerja perekonomian secara umum sebagai ukuran kemajuan suatu daerah. Indikator lain adalah tingkat pertumbuhan, pendapatan perkapita dan pergeseran atau perubahan struktur ekonomi (Sjafrizal, 2008).

Pertumbuhan PDRB tidak lepas dari peran setiap sektor-sektor ekonomi. Besar kecilnya kontribusi pendapatan setiap sektor ekonomi merupakan hasil perencanaan serta pertumbuhan yang dilaksanakan di daerah. Semakin besar sumbangan yang diberikan oleh masingmasing sektor terhadap PDRB suatu daerah maka akan dapat meningkatkan pertumbuhan ekonomi kearah yang lebih baik.

Provinsi Kalimantan Utara yang telah menjadi daerah otonomi sejak 25 Oktober 2012 yang memiliki kewenangan untuk menyelenggarakan pemerintah dan pembangunan serta memberikan pelayanan kepada masyarakat, memiliki kewenangan yang luas untuk mengelola, merencanakan dan memanfaatkan perekonomian secara optimal, yang dapat dinikmati oleh seluruh masyarakat di Provinsi Kalimantan Utara. Sektor ekonomi unggulan mempunyai peran yang sangat penting bagi suatu daerah khususnya Provinsi Kalimantan Utara, disamping untuk mendorong pertumbuhan sektorsektor lainnnya juga untuk meningkatkan pertumbuhan dan pembangunan ekonomi. Daerah yang dijadikan tempat penelitian oleh peneliti mengenai sektor ekonomi unggulan dalam pengembangan potensi pekonomian adalah Provinsi Kalimantan Utara. Peneliti memilih Provinsi Kalimantan Utara dikarenakan masih banyaknya potensi sektor ekonomi Provinsi Kalimantan Utara yang belum berkembang dan layak untuk dikembangkan. Memberikan sumbangan kontribusi yang besar terhadap pertumbuhan PDRB Provinsi Kalimantan Utara. Sektor-sektor lain yang perlu dikembangkan seperti yang dikatakan oleh kepala perwakilan Bank Indonesia (BI) Provinsi Kalimantan Utara, bapak Hendik Sudaryanto, prospek ekonomi Kaltara tahun 2018 meliputi enam sektor yaitu pertambangan, pertanian, konstruksi, transportasi, ekspor luar negeri serta fiskal. Di sektor pertambangan adanya peningkatan konsumsi domestik, peningkatan produksi serta perbaikan harga batu bara pada tahun 2017.

Selain itu hal yang melatar belakangi penelitian ini adalah pertumbuhan penduduk yang terus meningkat sehingga kebutuhan ekonomi juga bertambah dan untuk memenuhi kebutuhan ekonomi tersebut maka diperlukan penambahan pendapatan. Untuk meningkatkan penambahan pendapatan maka konsekuensinya harus difokuskan kepada pembangunan sektorsektor yang mempunyai keunggulan yang besar sehingga mendorong sektorsektor lainnya untuk dikembangkan atau perekonomian secara keseluruhan sehingga membuat peneliti tertarik untuk melakukan penelitian ini.

\section{RUMUSAN MASALAH}

Berdasarkan latar belakang tersebut maka rumusan masalah yang akan diteliti adalah: 1. Bagaimanaperubahan struktur ekonomi di Provinsi Kalimantan Utara pada tahun 2010-2017?

1. Bagaimana dampak pertumbuhan ekonomi nasional dan dampak 
pertumbuhan bauran industri nasional terhadap perekonomian Provinsi Kalimantan Utara pada tahun 20102017 ?

2. Sektor apa yang menjadi sektor ekonomi unggulan di Provinsi Kalimantan Utara pada tahun 20102017?

\section{TUJUAN PENELITIAN}

Adapun tujuan penelitian ini adalah untuk mengetahuiperubahan struktur ekonomi di Provinsi Kalimantan Utara pada tahun 20102017, untuk mengetahui dampak pertumbuhan ekonomi nasional dan dampak pertumbuhan bauran industri nasional terhadap perekonomian di Provinsi Kalimantan Utara pada tahun 2010-2017, dan untuk mengetahui seKtor yang menjadi seKtor ekonomi unggulan di Provinsi Kalimantan Utara pada tahun 20102017.

\section{TINJAUAN PUSTAKA}

\section{$\underline{\text { Pertumbuhan Ekonomi }}$}

Pengertian pertumbuhan ekonomi, menurut Prasetyo (2012) secara sederhana dapat dimaknai sebagai pertambahan output atau pendapatan nasional keseluruhan dalam kurun waktu tertentu.Perekonomian suatu negara dikatakan mengalami pertumbuhan jika jumlah balas jasa riil terhadap penggunaan faktor-faktor produksi pada tahun tertentu lebih besar dari tahun sebelumnya.Pertumbuhan ekonomi dianggap sebagai syarat dalam pembangunan (Pujoalwanto, 2014).Menurut teori neoklasik, tingkat pertumbuhan berasal dari tiga sumber yaitu akumulasi modal, bertambahnya penawaran tenaga kerja, dan peningkatan tenologi. Teknologi ini terlihat dari peningkatan skill atau kemajuan teknik sehingga produktivitas per kapita meningkat (Tarigan, 2005)

\section{Teori Pembangunan Ekonomi}

Pembangunan ekonomi adalah proses penciptaan suatu lingkungan oleh masyarakat yang mempengaruhi hasilhasil indikator ekonomi seperti

Kenaikan kesempatan kerja danpertumbuhan ekonomi (Kuncoro, 2004).Pembangunan ekonomi Arthus Lewis, Menurutnya, pembangunan ekonomi adalah pada dasarnya membahas proses pembangunan ekonomi yang terjadi di pedesaan dan perkotaan. Dalam teorinya, Lewis mengasumsikan bahwa perekonomian suatu negara pada dasarnya terbagi menjadi dua, yaitu perekonomian tradisional di pedesaan yang didominasi oleh sektor pertanian dan perekonomian modern di perkotaan dengan industri sebagai sektor utama (Tambunan, 2012).

Menurut Michael E. Porter (1990), strategipembangunan daerah seharusnya didasarkan pada keunggulan kompetitif (kompetitif advatange) dimana unsur ini lebih mengutamakan unsur kreatifitas, teknologi dan kualitas manusia yang dikombinasikan menjadi suatu kegiatan usaha yang mempunyai daya saing yang tinggi dengan daerah lainnya berbeda dengan unsur keunggulan komparatif yang bersifat tradisional yang hanya didasarkan pada perbedaan sumber daya alam yang dimiliki (Sjafrizal, 2008).

\section{$\underline{\text { Teori Perubahan Struktur Ekonomi }}$}

Teori-teori perubahan struktural memusatkan perhatian pada transformasi struktur ekonomi dari pola pertanian ke struktur yang lebih modern serta memiliki sektor industri manufaktur dan sektor jasajasa yang tangguh. Aliran pendekatan struktural ini didukung oleh Lewis yang terkenal dengan model teoritisnya "surplus tenaga kerja dua sektor" dan Chenery yang sangat terkenal dengan analisis empirisnya tentang "pola-pola pembangunan" (patterns of depelovment) (Todaro, 2003). 
Menurut Kuznets, perubahan struktur ekonomi atau disebut juga transformasi struktural, didefinisikan sebagai suatu rangkaian perubahan yang saling berkaitan satu sama lainnya dalam komposisi dari permintaan agregat, perdagangan luar negeri (ekspor dan impor), penawaran agregat (produksi dan penggunaan faktor-faktor produksi) yang disebabkan adanya proses pembangunan dan pertumbuhan ekonomi berkelanjutan (Todaro, 2000). Perubahan struktural mengandung arti peralihan dari masyarakat pertanian tradisional menjadi ekonomi industri modern, yang mencakup peralihan lembaga, sikap sosial, dan motivasi yang ada secara radikal. Perubahan struktural semacam ini menyebabkan kesempatan kerja semakin banyak, dan produktivitas buruh stok modal, pendayagunaan sumbersumber baru serta perbaikan teknologi akan semakin tinggi (Jhingan, 2010).

\section{$\underline{\text { Tinjauan Empiris }}$}

Salah satu data pendukung yang perlu dijadikan bagian tersendiri adalah penelitian terdahulu yang relevan dengan permasalahan dan metode yang sedang dibahas pada penelitian ini. Berikut merupakan penelitian terdahulu, berupa beberapa jurnal yang relevan dengan penelitian yang dilakukan:

1. Penelitian yang dilakukan oleh Afrendi Hari Tristanto (2013) yang berjudul "Analisis sektor ekonomi unggulan dalam pengembangan potensi perekonomian di Kota Blitar", dengan pendekatan sektor pembentuk PDRB. Metode yang digunakan adalah Analisis Location Quotient (LQ), dan Analisis Shift Share (SS). Dari hasil analisis menggunakan kedua alat yakni LQ dan Shift Share yang temasuk sektor ekonomi unggulan di Kota Blitar yakni: sektor listrik, gas dan air bersih, dan sektor bangunan/konstruksi. Kedua sektor tersebut termasuk sektor basis dan kompetitif
2. Penelitian yang dilakukan oleh Andik Waloyo (2018) yang berjudul "Analisis potensi ekonomi dan sektor unggulan ekonomi di Kabupaten Grobogan tahun 2010-2015", metode yang digunakan untuk menganalisis sektor unggulan dan perubahan struktur ekonomi dalam penelitian ini adalah analisis Shift Share Klasik, dan Shift Share Esteban Marquillas. Hasil penelitian menunjukkan bahwa sektor unggulan di Kabupaten Grobogan berdasarkan hasil uji analisis Shift Share Klasik, dan Shift Share Estaban Marquillas, dengan data 2010-2015 diketahui sektor yang unggul yaitu sektor pertanian, kehutanan, dan perikanan, sektor pengadaan listrik dan gas, sektor penyediaan akomodasi dan makan minum, sektor industri pengolahan.

3. Penelitian yang dilakukan oleh Bambang Kurniawan (2016) yang berjudul "Analisis sektor ekonomi unggulan Kabupaten Kerinci Provinsi Jambi”. Hasil pengujian DLQ menunjukkan bahwa sektor pengangkutan dan komunikasi, sektor gas, listrik dan air bersih, keuangan, persewaan dan jasa perusahaan, sektor pertambangan dan penggalian, sektor perdagangan hotel dan restoran, serta sektor jasa-jasa yang meiliki nilai DLQ $>1$ maka sektor tersebut merupakan sektoryang prospektif untuk dikembangkan lebih lanjut dalam upaya meningkatkan dan mendorong perekonomian daerah, sektor ini juga mampu bersaing dengan sektor perekonomian yang sama di luar Kabupaten Kerinci. Sektor pertanian dan jasa-jasa merupakan sektor basis yang merupakan sektor unggulan yang dapat menjadi pendorong bagi perkembangan sektor-sektor yang lainnya di Kabupaten Kerinci berdasarkan pendekatan Location Quotient, Dynaic Location Quotient,dan Shift Share. 
4. Pieter Noisirifan (2018) yang berjudul "Analisis sektor unggulan (LQ),struktur ekonomi (shift share), dan proyeksi produk domestik regional bruto Provinsi Papua 2018" menemukan bahwa sektor unggulan di Provinsi Papua adalah sektor pertambangan dan penggalian

\section{Definisi Konsep}

1. Perubahan Struktur Ekonomi Menurut Kuznets, perubahan struktur ekonomi atau disebut juga transformasi struktural, didefinisikan sebagai suatu rangkaian perubahan yang saling berkaitan satu sama lainnya dalam komposisi dari permintaan agregat, perdagangan luar negeri (ekspor dan impor), penawaran agregat (produksi dan penggunaan faktor-faktor produksi) yang disebabkan adanya proses pembangunan dan pertumbuhan ekonomi berkelanjutan (Todaro, 2000).

2. Pertumbuhan Ekonomi

Pengertian pertumbuhan ekonomi, menurut Prasetyo (2012) secara sederhana dapat dimaknai sebagai pertambahan output atau pendapatan nasional keseluruhan dalam kurun waktu tertentu (Pujoalwanto, 2014).

3. Sektor Unggulan Sektor ekonomi unggulan dapat didefinisikan sebagai sektor ekonomi yang mampu menunjang dan mempercepat pembangunan dan pertumbuhan perekonomian daerah yang mempunyai daya saing serta pengembangannya tidak mengakibatkan sektor lain menjadi "mati" dan menimbulkan kerusakan lingkungan yang parah (Widodo, 2006).

\section{$\underline{\text { Kerangka Penelitian }}$}

Pencapaian tujuan pembangunan daerah dapat dilihat dari perkembangan indikator ekonomi yang ada, salah satunya menggunakan data PDRB.Pembangunan ekonomi diarahkan untuk memperkokoh laju pertumbuhan ekonomi dengan keterkaitan yang kuat dan saling mendukung antar sektor dengan melihat sektor-sektor yang menjadi unggulan di Provinsi Kalimantan Utara.

Melihat segala keterbatasan sumber daya masing-masing daerah, maka dalam perencanaan pembangunan tersebut perlu ditentukan sektorsektor ekonomi yang akan menjadi sektor unggul dan menganalisa perubahan struktur ekonomi serta pertumbuhan ekonomi di Provinsi Kalimantan Utara agar perencanaan pembangunan tersebut dapat lebih terarah

Sektor-sektor ekonomi pembentuk PDRB di Provinsi Kalimantan Utara terdiri tujuh belas sektor antara lain: pertanian, kehutanan, dan perikanan; pertambangan dan penggalian; industri pengolahan; pengadaan listrik dan gas; pengadaan air, pengelolaan sampah, limbah dan daur ulang; konstruksi; perdagangan besar dan eceran, reparasi mobil dan sepeda motor; transportasi dan pergudangan; penyediaan akomodasi dan makan minum; informasi dan komunikasi; jasa keuangan; real estate; jasa perusahaan; administrasi pemerintahan, pertahanan dan jaminan sosial wajib; jasa pendidikan; jasa kesehatan dan kegiatan sosial; jasa lainnya.

Penelitian ini akan menganalisis perubahan struktur ekonomi, pertumbuhan ekonomi serta sektor ekonomi ekonomi unggulan di Provinsi Kalimantan Utara selama periode analisis. Struktur ekonomi dapat dilihat dari kontribusi masingmasing sektor ekonomi terhadap PDRB.Untuk menganalisis sektor ekonomi unggulan dan menganalisis pertumbuhan ekonomi digunakan metode analisis analisis Shift Share sehingga dapat diketahui sektor-sektor unggulan dan pertumbuhan ekonomi. Adapun kerangka pemikiran penelitian ini tersaji pada gambar di bawah ini : 


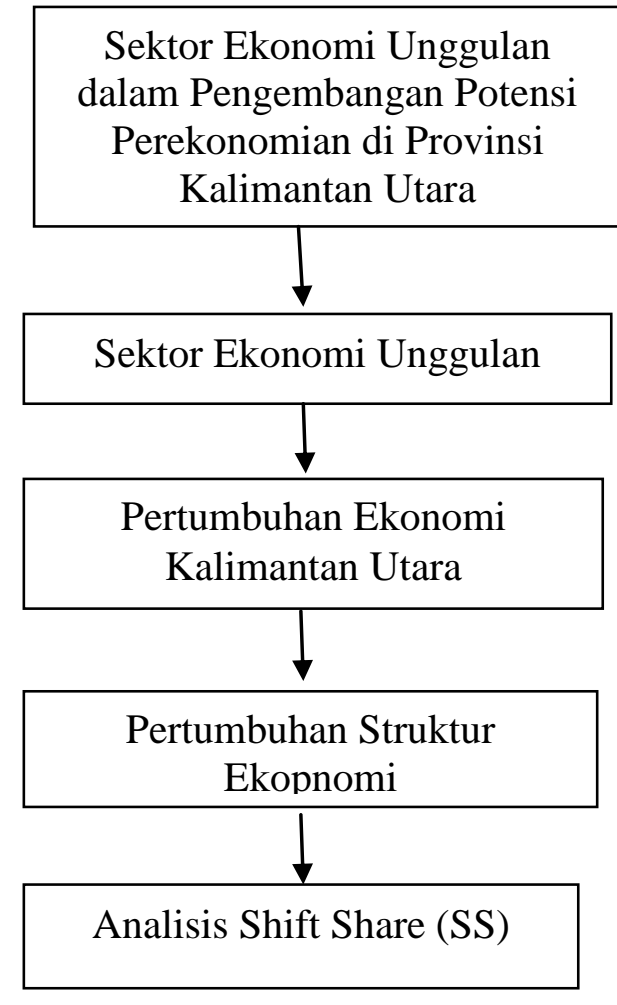

\section{METODE PENELITIAN}

Penelitian ini dilaksanakan pada semester ganjil tahun 2018/2019.Penelitian ini dilakukan mulai tanggal 10 bulan Januari tahun 2019 sampai dengan tanggal 05 bulan Februari 2019. Data yang digunakan dalam penelitian ini adalah data sekunder berupa data time series yang diperoleh dari Badan Pusat Statistik (BPS) Nasional (Indonesia) dan Badan Pusat Statistik (BPS) Provinsi Kalimantan Utara Atas Dasar Harga Konstan (ADHK) menurut lapangan usaha seri 2010. Alat analisis yang digunakan dalam penelitian ini yaitu analisis Shift Share.

\section{HASIL PENELITIAN}

Perubahan Strukur Ekonomi Provinsi $\underline{\text { Kalimantan Utara }}$
Total peningkatan PDRB (Dij), sektor pertanian, kehutanan dan perikanan menunjukkan jumlah positif sebesar $\mathrm{Rp}$ 3.184,67 miliar rupiah mempunyai arti bahwa pertumbuhan sektor pertanian, kehutanan dan perikanan di Provinsi Kalimantan Utara relatif lebih cepat dibandingkan dengan pertumbuhan PDRB sektor yang sama pada tingkat nasional. Sektor pertanian, kehutanan, dan perikanan memberikan kontribusi yang cukup besar terhadap pembentukan PDRB Provinsi Kalimantan Utara, hal tersebut diakibatkan masih adanya minat masyarakat terhadap sektor pertanian, kehutaan dan perikanan.

Total peningkatan PDRB (Dij), sektor pertambangan dan penggalian menunjukkan jumlah positif sebesar Rp 4.854,21 miliar rupiah mempunyai arti bahwa pertumbuhan sektor pertambangan dan penggalian di Provinsi Kalimantan Utara relatif

lebih cepat jika dibandingkan dengan pertumbuhan PDRB sektor yang sama pada tingkat nasional. Pertumbuhan sektor pertambangan dan penggalian di Provinsi Kalimantan Utara memberikan total peningkatan PDRB terbesar untuk perekonomian Provinsi Kalimantan Utara, hal tersebut dikarenakan Provinsi Kalimantan Utara memiliki potensi pertambangan seperti pertambangan batubara dan pertambangan migas merupakan salah satu sub sektor pertambangan yang memiliki peranan besar.

Total peningkatan PDRB (Dij), sektor industri pengolahan menunjukkan jumlah positif sebesar Rp 1.735,87 mempunyai arti bahwa pertumbuhan sektor industri pengolahan di Provinsi Kalimantan Utara relatif lebih cepat jika dibandingkan dengan pertumbuhan PDRB sektor yang sama pada tingkat nasional.

Total peningkatan PDRB (Dij), sektor pengadaan listrik dan gas menunjukkan nilai positif sebesar $\mathrm{Rp}$ 15,79 miliar rupiah mempunyai arti bahwa pertumbuhan sektor pengadaan listrik dan 
gas di Provinsi Kalimantan Utara relatif lebih cepat jika dibandingkan dengan jumlah pertumbuhan PDRB sektor yang sama pada tingkat nasional.

Total peningkatan PDRB (Dij), sektor pengadaan air, pengelolaan sampah, limbah dan daur ulang menunjukkan jumlah positif sebesar Rp 12,91 miliar rupiah mempunyi arti bahwa pertumbuhan sektor pengadaan air, pengelolaan sampah, limbah dan daur ulang di Provinsi Kalimantan Utara relatif lebih cepat jika dibandingkan dengan pertumbuhan

PDRB sector yang sama padatingkat

Nasional

Total peningkatan PDRB (Dij), sektor kontruksi menunjukkan jumlah positif sebesar Rp 2.492,73 miliar rupiah mempunyai arti bahwa

pertumbuhan sektor kontruksi di Provinsi Kalimantan Utara relatif lebih cepat jika dibandingkan dengan

pertumbuhan PDRB sektor yang sama pada tingkat nasional

Total peningkatan PDRB (Dij), sektor perdagangan besar dan eceran; reparasi mobil dan sepeda motor menunjukkan jumlah positif sebesar mempunyai arti bahwa pertumbuhan sektor perdagangan besar dan eceran; reparasi mobil dan sepeda motor di Provinsi Kalimantan Utara relatif lebih cepat jika dibandingkan dengan pertumbuhan PDRB sektor yang sama pada tingkat nasional.

Total peningkatan PDRB (Dij), sektor transportasi dan pergudangan menunjukkan jumlah positif sebesar $\mathrm{Rp}$ 1530,15 miliar rupiah mempunyai arti bahwa pertumbuhan sektor transportasi dan pergudangan di Provinsi Kalimantan Utara relatif lebih cepat jika dibandingkan dengan pertumbuhan PDRB sektor yang sama pada tingkat nasional

Total peningkatan PDRB (Dij), sektor penyediaan akomodasi dan makan minum menunjukkan jumlah positif sebesar Rp 304,68 miliar rupiah mempunyai arti bahwa pertumbuhan sektor penyediaan akomodasi dan makan minum di Provinsi Kalimantan Utara relatif lebih cepat jika dibandingkan dengan

pertumbuhan PDRB sektor yang sama pada tingkat nasional

Total peningkatan PDRB (Dij), sektor informasi dan komunikasi menunjukkan jumlah positif sebesar Rp 812,92 miliar rupiah mempunyai arti bahwa pertumbuhan sektor informasi dan komunikasi di Provinsi Kalimantan Utara relatif lebih cepat jika dibandingkan dengan pertumbuhan PDRB sektor yang sama pada tingkat nasional.

Total peningkatan PDRB (Dij), sektor jasa keuangan dan asuransi menunjukkan jumlah positif sebesar Rp 214,74 miliar rupiah mempunyai arti bahwa pertumbuhan keuangan dan asuransi di Provinsi Kalimantan Utara relatif lebih cepat jika dibandingkan dengan pertumbuhan PDRB sektor yang sama pada tingkat nasional

Total peningkatan PDRB (Dij), sektor real estat menunjukkan jumlah positif sebesar Rp 193,27 miliar upiah mempunyai arti bahwa

pertumbuhan sektor real estat di Provinsi Kalimantan Utara relatif lebih cepat jika dibandingkan dengan

pertumbuhan PDRB sektor yang sama pada tingkat nasional

Total peningkatan PDRB (Dij), sektor jasa perusahaan menunjukkan jumlah positif sebesar Rp 36,79 miliar rupiah mempunyai arti bahwa pertumbuhan sektor jasa perusahaan di Provinsi Kalimantan Utara relatif lebih cepat jika dibandingkan dengan pertumbuhan PDRB sektor yang sama pada tingkat nasional

Total peningkatan PDRB (Dij), sektor administrasi pemerintahan, pertahanan dan jaminan sosial wajib menunjukkan jumlah positif sebesar Rp 1.031,44 miliar rupiah mempunyai arti bahwa pertumbuhan sektor jasa perusahaan di Provinsi Kalimantan Utara relatif lebih cepat jika dibandingkan 
dengan pertumbuhan PDRB sektor yang sama pada tingkat nasional.

Total peningkatan PDRB (Dij), sektor jasa pendidikan menunjukkan jumlah positif sebesar Rp 745,66 miliar rupiah mempunyai arti bahwa pertumbuhan sektor jasa pendidikan di Provinsi Kalimantan Utara relatif lebih cepat jika dibandingkan dengan pertumbuhan PDRB sektor yang sama pada tingkat nasional

Total peningkatan PDRB (Dij), sektor jasa kesehatan dan kegiatan sosial menunjukkan jumlah positif sebesar $\mathrm{Rp}$ 314,40 miliar rupiah mempunyai arti bahwa pertumbuhan sektor jasa kesehatan dan kegiatan sosial di Provinsi Kalimantan Utara relatif lebih cepat jika dibandingkan dengan pertumbuhan PDRB sektor yang sama pada tingkat nasional

Total peningkatan PDRB (Dij), sektor jasa lainnya menunjukkan jumlah

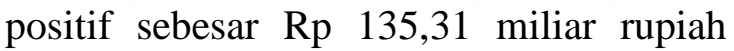
mempunyai arti bahwa pertumbuhan sektor jasa lainnya di Provinsi Kalimantan Utara relatif lebih cepat jika dibandingkan dengan pertumbuhan PDRB sektor yang sama pada tingkat nasional

Provinsi Kalimantan Utara tidak mengalami perubahan struktur ekonomi. Hal tersebut dikarenakan sektor pertanian, kehutanan, dan perikanan dan sektor pertambangan dan penggalian (sektor primer) yang

mendominasi baik pertumbuhan PDRB maupun total peningkatan PDRB (Dij). Sejalan dengan hal tersebut, sektor primer dijadikan salah satu tujuan dan sasaran Rencana Pembangunan Jangka Menengah Daerah (RPJMD) oleh pemerintah Provinsi Kalimantan Utara dengan meningkatkan perekonomian rakyat yang berkelanjutan yakni pada peningkatan angka pertumbuhan ekonomi sebagai penanda meningkatnya pertumbuhan ekonomi secara umum di masyarakat perlu diawali dengan upaya peningkatan infrastruktur fisik pertanian, upaya Peningkatan ketersediaan sarana produksi pertanian, upaya peningkatan pemanfaatan lahan pertanian, upaya peningkatan kuantitas dan kualitas Sumber Daya Manusia (SDM) pertanian, upaya peningkatan pengelolaan dan kelembagaan perekonomian rakyat, upaya peningkatan pengelolaan perikanan budidaya dan perikanan tangkap, upaya peningkatan produktivitas perikanan budidaya, upaya peningkatan pengelolaan pesisir, pulaupulau kecil dan pengawasan sumberdaya kelautan dan perikanan, upaya peningkatan daya tarik pariwisata secara terpadu dan berkelanjutan, upaya peningkatan kualitas SDM dan kelembagaan kepariwisataan, upaya pengembangan sistem informasi manajemen dan pemasaran pariwisata, upaya peningkatan produksi pertambangan, upaya peningkatan kualitas hasil pertambangan, peningkatkan SDM pertambangan, upaya peningkatan pengelolaan dan pengendalian lingkungan, serta upaya peningkatan

teknologi pengembangan ekonomi yang berdaya saing.

Sektor ekonomi yang termasuk dalam sektor sekunder adalah sektor industri pengolahan, sektor pengadaan listrik dan gas, sektor pengadaan air, pengelolaan sampah, limbah dan daur ulang, sektor kontruksi. Kemudian, sektor ekonomi yang termasuk dalam sektor tersier adalah sektor perdagangan besar dan eceran; reparasi mobil dan sepeda motor, sektor transportasi dan pergudangan, sektor penyediaan akomodasi dan makan minum, sektor informasi dan komunikasi, sektor jasa keuangan dan asuransi, sektor real estat, sektor jasa perusahaan, sektor administrasi pemerintahan, pertahanan dan jaminan sosial wajib, sektor jasa pendidikan, sektor jasa kesehatan dan kegiatan sosial, dan sektor jasa lainnya.

Dampak Pertumbuhan Ekonomi Nasional dan Dampak Pertumbuhan Bauran Industri Nasional terhadap Perekonomian Provinsi $\underline{\text { Kalimantan Utara }}$ 
Berdasarkan komponen analisis shift share yakni komponen $\mathrm{Nij}$ dan komponen Mij terhadap perekonomian Provinsi Kalimantan Utara menemukan bahwa:

1. Secara riil, pengaruh luar ini telah mengakibatkan pertumbuhan ekonomi nasional sebesar Rp 15.769,41 miliar rupiah. Kondisi ini menunjukkan bahwa 80,39 persen peningkatan PDRB Provinsi Kalimantan Utara disebabkan oleh pertumbuhan perekonomian agregat nasional yang merupakan faktor eksternal dari Provinsi Kalimantan Utara. Pengaruh perekonomian nasional terlihat kentara pada sektor jasa perusahaan, yaitu sebesar 1,26 persen. Akibat dari pengaruh yang kuat terhadap sektor sesungguhnya dapat meningkatkan petumbuhan ekonomi PDRB sektor jasa perusahaan di Provinsi Kalimantan Utara sebesar Rp 46,26 miliar rupiah. Pengaruh luar yang besar pada kegiatan sektor jasa ini menandakan bahwa Provinsi Kalimantan Utara yang mempunyai sarana bisnis yang terkelola dengan baik seperti pengunaan atau pemanfaatan jasa periklanan dibutuhkan mempromosikan jenis produk barang maupun jasa. Agar produk yang ditawarkan dapat dikenali oleh masyarakat. Dengan adanya pengaruh eksternal ini yang digulirkan kepada seluruh wilayah Indonesia termasuk Provinsi Kalimantan Utara, sektor ini mampu memberikan pertumbuhan yang cukup besar di Provinsi Kalimantan Utara. Secara umum, membaiknya kondisi Pendapatan Domestik Bruto (PDB) Nasional dalam periode analisis cukup mempengaruhi kinerja seluruh sektor-sektor di Provinsi Kalimantan Utara. Beberapa sektor di pengaruhi secara signifikan, tetap ada juga yang terpengaruh tidak terlalu signifikan.

2. Kemudian akibat dampak pertumbuhan ekonomi sektoral nasional terhadap perekonomian Provinsi Kalimantan Utara menurun sebesar 19,70 persen. Penurunan PDRB, menunjukkan bahwa struktur pertumbuhan ekonomi nasional justru melemahkan perekonomian di Provinsi Kalimantan Utara. Sektor yang memperoleh dampak negatif, bauran industri dari nasional adalah sektor pertanian, kehutanan dan perikanan sebesari 0,27 persen, sektor pertambangan dan penggalian sebesar 0,80 persen, sektor industri pengolahan sebesar 0,13 persen, sektor pengadaan listrik dan gas sebesar 0,06 persen, sektor pengadaan air,

pengelolaan sampah, limbah dan daur ulang sebesar 0,16 persen, sektor perdagangan bersar dan eceran; reparasi mobil dan sepeda motor sebesar 0,06 persen, dan sektor administrasi pemerintahan, pertahanan dan jaminan sosial wajib sebesar 0,33 persen. Adapun sektor yang memperoleh dampak bauran industri positif yang sangat kuat adalah sektor konstruksi sebesar 0,020 persen, sektor trasportasi pergudangan sebesar 0,25 persen, sektor penyedia akomodasi dan makan minum sebesar 0,06 persen, sektor informasi dan komunikasi sebesar 0,47 persen sektor jasa keuangan dan asuransi sebesar 0,39 persen, sektor real estate sebesar 0,02 persen, sektor jasa perusahaan sebesar 0,81 persen, sektor jasa pendidikan sebesar 0,04 persen, sektor jasa kesehatan dan kegiatan sosial sebesar 0,18 persen, dan sektor jasa lainnya sebesar 0,31 persen.

$\underline{\text { Sektor Unggulan di Provinsi Kalimantan }}$ Utara

Berdasarkan identifikasi keunggulan kompetitif, sektor ekonomi unggulan di Provinsi Kalimantan Utara adalah sektor pertanian, kehutanan, dan perikanan, sektor pertambangan dan penggalian, sektor industri pengolahan, 
sektor pengadaan listrik dan gas, sektor pengadaan air, pengelolaan sampah, limbah dan daur ulang, sektor konstruksi, sektor perdagangan besar dan eceran; reparasi mobil dan sepeda motor, sektor transportasi dan pergudangan, sektor penyedia akomodasi dan makan minum, sektor informasi dan komunikasi, sektor real estate, sektor administrasi pemerintahan, pertahanan dan jaminan sosial wajib, sektor jasa pendidikan, sektor jasa kesehatan dan kegiatan sosial, serta sektor jasa lainnya. Hasil penelitian ini sejalan dengan penelitian yang dilakukan oleh Andik Waloyo (2018) menemukan bahwa sektor unggulan di Kabupaten Grobongan adalah sektor pertanian, kehutanan, dan perikanan.Bambang Kurniawan (2016) menemukan bahwa sektor unggulan di Kabupaten Kerinci adalah sektor pertanian.Anna Yulianita (2009) menemukan bahwa sektor unggulan di Kabupaten Ogan Kemering Ilir adalah sektor pertanian.Afrendi Hari Tristanto (2013) menemukan bahwa sektor unggulan di Kota Blitar adalah sektor listrik, gas dan air bersih, dan sektor bangunan/konstruksi.Pieter Noisirifan (2018) menemukan bahwa sektor unggulan di Provinsi Papua adalah sektor pertambangan dan penggalian.Hajeri, dkk (2015) menemukan bahwa sector unggulan di Kabupaten Kubun Raya adalah sektor transportasi dan komunikasi.

Analisis sektor ekonomi unggulan

dalam pengembangan potensi perekonomian diperlukan sebagai dasar untuk kebijakkan pembangunan ekonomi di Provinsi Kalimantan Utara dimasa mendatang.Sehingga kebijaksanaan pembangunan ekonomi dapat diarahkan untuk menggerakkan sektor-sektor tersebut. Prioritas pembangunan ekonomi di Provinsi Kalimantan Utara haruslah didasarkan pada sektor unggulan, tidak hanya didasarkan pada sumberdaya alam yang dimiliki, tetapi juga memperhatikan teknologi dan kualitas sumber daya manusia, sehingga output yang dihasilkan akan mempunyai daya saing yang tinggi, karena didukung oleh potensi spesifik yang dimiliki daerah. Pemerintah Provinsi Kalimantan Utara dapat mengembangkan seperti sektor pertanian, kehutanan dan perikanan menyediakan pupuk dengan harga murah, pemberian pinjaman yang sifatnya tidak mendesak para petani atau nelayan dengan cara mengembalikan uang ke perbankan atau koperasi setempat setelah panen tiba, menyediakan bibit unggul serta adanya edukasi tentang kreativitas bagi petani dan nelayan untuk meningkatkan pendaptan petani dan nelayan. Kemudian sektor pertambangan dan penggalian dapat memperluas jaringan kemitraan antar perusahaan, serta memberikan pemahaman kepada perusahaanperusahaan untuk memanfaatkan sumber daya alam (mineral, batubara dan emas) dengan baik serta memperhatikan kondisi lingkungan.

\section{KESIMPULAN}

Berdasarkan hasil analisis dan pembahasan tentang analisis sector ekonomi unggulan dalam pengembangan potensi perekomian di Provinsi Kalimantan Utara tahun 2010-2017, maka dapat disimpulkan sebagai berikut:

1. Berdasarkan hasil analisis Shift Share yang terbagi ke dalam tiga komponen yaitu nasional share (NS) atau Nij terhadap pertumbuhan ekonomi Provinsi Kalimantan Utara memiliki respon positif yakni sebesar Rp. 15.769,41 miliar rupiah. Sementara itu pada proportional shift (PS) atau bauran industri atau Mij menunjukkan pertumbuhan ekonomi sektoral terhadap peningkatan PDRB Provinsi Kalimantan Utara memberikan respon negatif yakni sebesar Rp. 3.864,89 miliar rupiah. Sedangkan pengaruh komponen diferential shift (DS) atau $\mathrm{Cij}$, sektor unggulan kompetitif memberikan respon positif yakni sebesar Rp. 7.711,39 miliar rupiah. Perubahan struktur ekonomi 
yang terjadi pada sektorsektor ekonomi Provinsi Kalimantan Utara dari sektor pertambangan dan penggalian mengalami ke sektor pertanian, kehutanan dan perikanan

2. Berdasarkan analisis Shift Share menemukan bahwa akibat dampak pertumbuhan ekonomi nasional terhadap perekonomian Provinsi Kalimantan Utara sebesar 80,39 persen. Kondisi ini menunjukkan bahwa peningkatan PDRB Provinsi Kalimantan Utara disebabkan oleh pertumbuhan perekonomian agregat nasional yang merupakan faktor eksternal dari Provinsi Kalimantan Utara. Kemudian akibat dampak pertumbuhan ekonomi bauran industri nasional terhadap perekonomian Provinsi Kalimantan Utara menurun sebesar 19,70 persen. Penurunan PDRB, menunjukkan bahwa struktur pertumbuhan ekonomi nasional justru melemahkan perekonomian di Provinsi Kalimantan Utara.

3. Berdasarkan identifikasi keunggulan kompetitif, sektor ekonomi unggulan di Provinsi Kalimantan Utara adalah sektor pertanian, kehutanan, dan perikanan, sektor pertambangan dan penggalian, sektor industri pengolahan, sektor pengadaan listrik dan gas, sektor pengadaan air, pengelolaan sampah, limbah dan daur ulang, sektor konstruksi, sektor perdagangan besar dan eceran; reparasi mobil dan sepeda motor, sektor transportasi dan pergudangan, sektor penyedia akomodasi dan makan minum, sektor informasi dan komunikasi, sektor real estate, sektor administrasi pemerintahan, pertahanan dan jaminan sosial wajib, sektor jasa pendidikan, sektor jasa kesehatan dan kegiatan sosial, serta sektor jasa lainnya

\section{SARAN}

Berdasarkan dari kesimpulan penelitian ini, maka dapat dikemukakan saran-saran sebagai berikut :

1. Bagi badan perencanaan pembangunan daerah Provinsi Kalimantan Utara dalam merencanakan potensi ekonomi di Provinsi Kalimantan Utara perlu mempertimbangkan sektor yang mempunyai keunggulan yaitu sektor pertanian, kehutanan, dan perikanan dan sektor pertambangan dan penggalian serta mendorong sektorsektor ekonomi agar terciptanya spesialialisasi sektoral ekonomi.

2. Bagi pemerintah daerah Provinsi Kalimantan Utara untukmembuat kebijakan-kebijakan guna mengembangkan potensi ekonomi daerah, perlu memperhatikan dan mempertimbangkan sektor yang mempunyai keunggulan, selain itu juga harus memperhatikan sektor-sektor yang mempunyai keunggulan kompetitif karena sektor-sektor tersebut sangat berpengaruh terhadap pertumbuhan ekonomi Provinsi Kalimantan Utara

3. Bagi akademisi sebagai bahan referensi penelitian dan informasi terkait dengan sektor unggulan. Dalam penelitian selanjutnya perlu membandingkan dengan alat analisa lain yang berbasis tentang keunggulan atau potensi ekonomi seperti analisis Location Quatient analisis Shift Share Estaban Marquillas, dan lain sebagainya.

\section{DAFTAR PUSTAKA}

Adisasmita, H. Rahardjo. 2005. DasarDasar Ekonomi Wilayah. Makassar: Graha Ilmu

Badan Pusat Statistik. 2017. Produk Domestik Regional Bruto di Provinsi Kalimantan Utara Menurut Lapangan Usaha 2010-2016

Badan Pusat Statistik. 2017. Data Publikasi 2013-2017 PDRB ADHK Menurut Lapangan 
Usaha Provinsi Kalimantan Utara

Badan Pusat Statistik. 2017. Laju Pertumbuhan PDRB Provinsi Kalimantan Utara ADHK Menurut Lapangan Usaha 20102017

Badan Pusat Statistik.2017. Produk Domestik Regional Bruto Provinsi Kalimantan Utara ADHK Menurut Lapangan Usaha 2010-2016.

Badan Pusat Statistik2018. Produk Domestok Bruto Nasional ADHK Menurut Lapangan Usaha 20102017

Jhingan, M.L. 2010. Ekonomi Pembangunan dan Perencanaan. Jakarta: PT. Raja Persada.

Kuncoro, Mudrajad. 2004. Otonomi \& Pembangunan Daerah. Jakarta: Erlangga.

Lincolin, Arsyad. 1999. Pengantar Perencanaan Pembangunan Ekonomi Daerah, Edisi Kedua, Yogyakarta: BPFE.

Lincolin, Arsyad. 2010. Ekonomi Pembanguan. Salemba Ampat: Jakarta

Lincolin, Arsyad. 2016.Pengantar Perencanaan Pembangunan Ekonomi Daerah, Edisi Ketiga. Yogyakarta:BPFE

Martono, Nanang. 2012. Metode Penelitian Kualitatif, Analisis Isi dan Analisis Data Sekunder.Jakarta: PT Raja Grafindo Persada.

Pujoalwanto, Basuki. 2014. Perekonomian Indonesia Tinjauan Historis, Teoritis, dan Empiris.Yogyakarta: Jambusari.

Rencana Pembangunan Jangka Menengah Daerah (RPJMD) Provinsi Kalimantan Utara Tahun 20162021. Diunduh darihttp://ppid.kemendagri.go.id/f ront/dokumen/download/3000143 60
Sjafrizal. 2008. Ekonomi Regional Teori dan Aplikasi. Catatan Pertama. Baduose Media: Padang

Sugiono. 2011. Metode Penelitian Pendidikan (Pendekatan Kuantitatif, Kualitatif, dan $R \& D)$. Bandung : Alfa Beta.

Sugiono. 2013. Metode Penelitian Pendidikan (Pendekatan Kuantitatif, Kualitatif, dan $R \& D)$. Bandung: Alfabeta.

Sukirno, Sadono. 2000. Makroekonomi Modern: Perkembangan Pemikiran dari Klasik hingga Keynesian Baru. Jakarta: PT. Raja Grafindo Persada

Tambunan, T. T. H. 2001. Perekonomian Indonesia: teori dan temuan empiris. Jakarta: Ghalia.

Tambunan,.2012. Perekonomian Indonesia Teori dan Temuan Empiris. Jakarta : Ghalia.

Tarigan, Robinson. 2005. Ekonomi Regional (Teori dan Aplikasi).Jakarta: Bumi Aksara.

Todaro, Michael P. 2000. Pembangunan Ekonomi di Dunia Ketiga. Jilid 1. Erlangga: Jakarta

Todaro, 2003. Pembangunan Ekonomi Di Dunia Ketiga. Jilid 2. Edisi kedelapan. Jakarta: Erlangga

Widodo, Tri. 2006. Perencanaan Pembangunan: Aplikasi Komputer (Era Otonomi Daerah). Yogyakarta: UPP STIM YKPN 
